\title{
Degradation of Paracetamol and Its Oxidation Products in Surface Water by Electrochemical Oxidation
}

\author{
Miguel Ángel López Zavala* and Camila Renee Jaber Lara \\ Tecnológico de Monterrey, Water Center for Latin America and the Caribbean, Monterrey, Nuevo León, Mexico.
}

Received: January 15, 2018 Accepted in revised form: May 9, 2018

\begin{abstract}
Paracetamol and its toxic transformation products have been found in surface water, wastewater, and drinking water. Effective methods to degrade these products must be found to reduce their detrimental effects on microorganisms in aquatic systems and minimize the concern on human health. Thus, this study looked into the electrochemical oxidation of paracetamol and its oxidation products on surface water, and results were compared with those of paracetamol synthetic solution oxidation. Degradation of paracetamol was conducted using a stainless steel electrode cell, a pH of 3, and direct current densities of $5.7 \mathrm{~mA} / \mathrm{cm}^{2}(6 \mathrm{~V})$ and $7.6 \mathrm{~mA} / \mathrm{cm}^{2}(12 \mathrm{~V})$. For both current densities applied, the pharmaceutical and its oxidation products observed by high-performance liquid chromatography with diode-array detection (HPLC-DAD) at $254 \mathrm{~nm}$ were totally degraded. Faster degradation of paracetamol was observed at a higher current density. Indeed, 95\% of paracetamol was oxidized in only $15 \mathrm{~min}$ at the $7.6 \mathrm{~mA} / \mathrm{cm}^{2}$ current density. In comparison to the paracetamol synthetic solution's oxidation, degradation of paracetamol was faster in the surface water than the synthetic solution, at $5.7 \mathrm{~mA} / \mathrm{cm}^{2}$. Nevertheless, at $7.6 \mathrm{~mA} / \mathrm{cm}^{2}$, total degradation of paracetamol in surface water was delayed up to $40 \mathrm{~min}$, versus $7.5 \mathrm{~min}$ in the synthetic solution. Three oxidation products, observed by HPLC-DAD at $254 \mathrm{~nm}$, were fully oxidized. In comparison with the paracetamol synthetic solution, degradation of the oxidation products in surface water was faster than in synthetic solutions for both current densities. Furthermore, the $7.6 \mathrm{~mA} / \mathrm{cm}^{2}$ current density resulted in faster degradation of oxidation products. Results obtained from this work are promising for practical applications because short reaction times and low current densities are needed for degradation of paracetamol and its oxidation products. These densities can be potentially supplied by photovoltaic cells.
\end{abstract}

Keywords: active chlorine species; direct current (DC); electrochemical oxidation; oxidation products; paracetamol; surface water

\section{Introduction}

$\mathbf{P}$ ARACETAMOL IS ONE of the most commonly prescribed pharmaceutical drugs (Yang et al., 2008; Lourenção et al., 2009; Solé et al., 2010; Wu et al., 2012), as it has been reported as safe for human usage in analgesic and antipyretic therapy (Xu et al., 2008). It is considered one of the three most prescribed drugs, and is ranked among the 200 top prescriptions in the United States (Zhang et al., 2008; Wu et al., 2012).

*Corresponding author: Tecnológico de Monterrey, Water Center for Latin America and the Caribbean, Av. Eugenio Garza Sada Sur No. 2501, Col. Tecnológico, Monterrey C.P. 64849, Nuevo León, Mexico. Phone: +52-81-8358-2000 (ext. 5678); Fax: +52-81-8358-2000, (ext. 5560); E-mail: miganloza@itesm.mx

(C) Miguel Ángel López Zavala and Camila Renee Jaber Lara 2018; Published by Mary Ann Liebert, Inc. This Open Access article is distributed under the terms of the Creative Commons License (http:// creativecommons.org/licenses/by/4.0), which permits unrestricted use, distribution, and reproduction in any medium, provided the original work is properly cited.
Paracetamol has been found in aquatic ecosystems in the wild. This compound reaches the natural environment either through direct disposal of domestic drugs, discharges of feces/urine, or the inappropriate treatment of industrial effluents (Ganiyat, 2008; Yang et al., 2008). The toxicity of paracetamol has been documented extensively in animals and humans (Jaeschke and Bajt, 2006; Brind, 2007; Xu et al., 2008); nevertheless, there are a lack of studies focusing on marine/aquatic communities that are particularly vulnerable, especially filter feeders that can accumulate large amounts of pharmaceuticals within their bodies. Paracetamol contains three functional groups: the hydroxyl group $(\mathrm{OH})$, the amide group (HN-CO-R), and the aromatic group (benzene ring), as shown in Fig. 1.

Wastewater treatment plant (WWTP) effluent is considered the main source of paracetamol in surface waters (Bolong et al., 2009; Kasprzyk-Hordern et al., 2009). The development of effective water treatment processes for degrading pharmaceuticals is a new challenge for the scientific community. Many studies have been conducted with a main purpose of finding an effective and viable method to degrade 


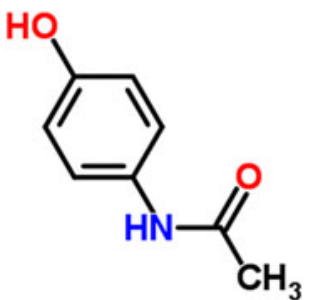

FIG. 1. Functional groups of paracetamol.

paracetamol. Among them, the following can be mentioned: electrocatalysis (Sánchez-Obrero et al., 2011); photo-Fenton (Durán et al., 2011); chemical (Hiremath et al., 2006); sonolysis (Quesada-Peñate et al., 2009); nonthermal plasma (Baloul et al., 2016); photocatalysis (Kanakaraju et al., 2014); reverse osmosis (Al-Rifai et al., 2007); activated carbon (Rossner et al., 2009); chlorination (Bedner and Maccrehan, 2006); and ozonation (Westerhoff et al., 2005). In previous studies, only partial degradation of paracetamol was reported, between $14 \%$ and $88 \%$ (Basavaraju et al., 2011; Durán et al., 2011), instead of total mineralization.

Furthermore, in most studies, the intermediates/oxidation products were not degraded (Nematollahi et al., 2009; Trovó et al., 2012), the reaction times were too long (Edrees et al., 2017), a high voltage was used (from 600 to $1,400 \mathrm{~V}$ ), and a continuous injection of oxygen to generate $\mathrm{H}_{2} \mathrm{O}_{2}$ was required, resulting in very costly and ineffective methods. In recent decades, the development of technologies such as electrochemical oxidation processes have reached a promising stage of progress, providing versatility, energy efficiency, automation, environmental compatibility, and cost effectiveness, which with correct application are now used effectively in micropollutant removal (Anglada et al., 2009).

However, an inconvenience of applying electrochemical oxidation to degrade emerging pollutants is the generation of intermediates/oxidation products (Zhao et al., 2009). During the electro-oxidation of paracetamol conducted by Brillas et al. (2005) using a boron-doped diamond and platinum (Pt) anode at a $\mathrm{pH}$ range of 2.0-12.0, a release of $\mathrm{NH}_{4}^{+}$and $\mathrm{NO}_{3}^{-}$ ions was observed in both anodes. In addition, hydroquinone and 1,4-benzoquinone were detected, while oxalic and oxamic acids were identified as ultimate carboxylic acids. Furthermore, p-aminophenol, p-nitrophenol, and NAPQI (N-acetylbenzoquinone imine) have been detected in the advanced oxidation of paracetamol (Bedner and Maccrehan, 2006; Moctezuma et al., 2012; Postigo and Richardson, 2014).

These by-products have the potential of having high levels of toxicity and/or could be even more bio-recalcitrant than the initial compound, making them harder to degrade using typical methods (Anglada et al., 2009). For this reason, the degradation of not only paracetamol but also its oxidation products is of paramount importance. In this regard, López Zavala and Espinoza Estrada (2016) successfully oxidized paracetamol and its transformation products in synthetic solutions by using an electrochemical oxidation cell with stainless steel electrodes. However, due to constituents of surface water that could affect the effectiveness of paracetamol oxidation, it was necessary to evaluate the performance of the process when real surface water is treated.

Thus, in this study, electrochemical oxidation of paracetamol and its oxidation products in surface water was conducted under the optimum oxidation conditions obtained by López Zavala and Espinoza Estrada (2016) for synthetic solutions ( $\mathrm{pH} 3$ and direct current (DC) densities of 5.7 and $7.6 \mathrm{~mA} / \mathrm{cm}^{2}$ ) and the results were compared with those of paracetamol synthetic solution oxidation. The results obtained in this study are promising for practical applications because not only the paracetamol was degraded but also its oxidation products; additionally, short reaction times and low DC densities were needed. Such DC densities can be potentially supplied by photovoltaic cells.

\section{Materials and Methods}

\section{Chemicals and materials}

Acetaminophen (4-acetamidophenol, 98\%), potassium hydroxide $(\mathrm{KOH})$, and sulfuric acid $\left(\mathrm{H}_{2} \mathrm{SO}_{4}\right)$, were obtained from Sigma-Aldrich (Toluca, Mexico). Hydrochloride acid ( $\mathrm{HCl})$ at $37 \%$ was purchased from Fermont (Mexico City, Mexico). Acetic acid was supplied by Fisher Scientific (Monterrey, Mexico). Methanol was provided by J.T. Baker (Center Valley, PA). Ultrapure water was obtained from a Milli-Q water purification system purchased from Bedford, MA. Surface water was collected from the dam "Rodrigo Gómez" located in Santiago, Nuevo León, Mexico, near the city of Monterrey.

\section{Experimental device}

A home-built fiberglass electrochemical oxidation cell, reported by López Zavala and Espinoza Estrada (2016), was used to run all the tests, and it is presented in Fig. 2. The device has a total volume of $180 \mathrm{~mL}$. In the third plate, a mesh of stainless steel electrodes is configured, and prepared based on a textile technique reported by Abidin et al. (2007). The dimensions of the mesh are $107 \times 60 \mathrm{~mm}$; it is integrated by 27 electrodes made of 24 American Wire Gauge (AWG) stainless steel wire with a $0.56 \mathrm{~mm}$ diameter, length of $107 \mathrm{~mm}$, and spaced at $2.1 \mathrm{~mm}$ each. Thirteen electrodes functioned as cathodes and the other 14 worked as "active" anodes. The electrodes had a terminal connected to a DC power supplier (Kaselco from Seal Beach, CA) that can supply a voltage between 0 and $50 \mathrm{~V}$, and a current intensity between 0 and $10 \mathrm{~A}$. The electrochemical oxidation cell can be operated on either batch or continuous flow schemes; but in this study, batch operation was conducted.

\section{Characterization of surface water}

Bulk characterization of surface water was conducted based on parameters such as $\mathrm{pH}$, electrical conductivity (EC), chemical oxygen demand (COD), turbidity, total solids (TS), total dissolved solids (TDS), and paracetamol concentration. The $\mathrm{pH}$ and EC were determined by using a Thermo Scientific Orion 3-Star equipment (Thermo Fisher Scientific, Waltham, MA). Turbidity was measured based on the nephelometric method by using a Hach $2100 \mathrm{~N}$ Turbidimeter (USA Hach Company, Loveland, CO). COD, TS, and TDS were determined based on the standard methods for the analysis of water and wastewater (APHA, AWWA, and WEF, 2005). Paracetamol in surface water was analyzed by high-performance liquid chromatography using an Agilent 1200 HPLC-DAD system (Agilent Technologies, Santa Clara, CA). 


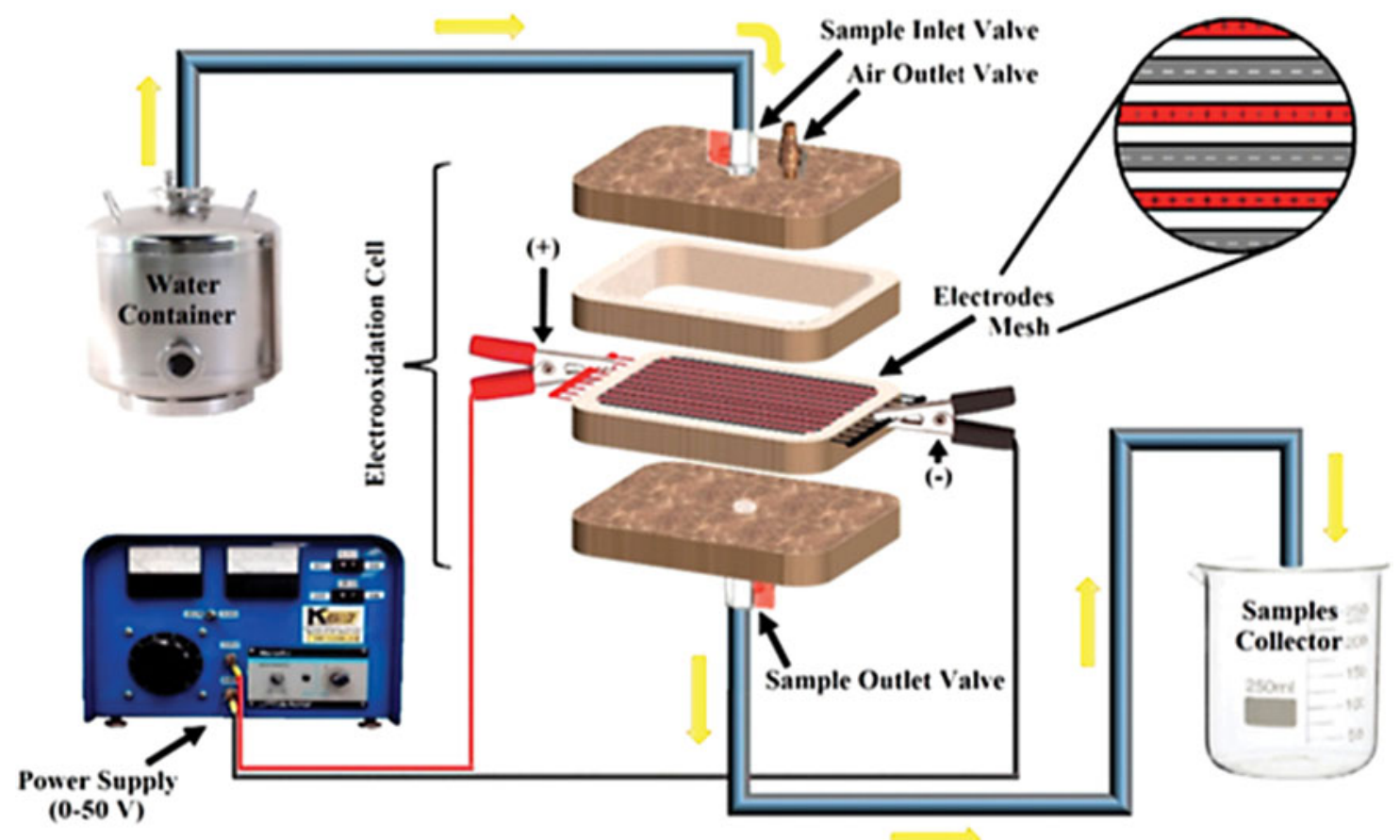

FIG. 2. Electrochemical oxidation cell (López Zavala and Espinoza Estrada, 2016).

\section{Degradation of paracetamol and its oxidation products}

Solutions of $10 \mathrm{mg} / \mathrm{L}$-paracetamol were prepared using surface water. The solution $\mathrm{pH}$ was adjusted from 6.8 to 3.0 by adding $\mathrm{HCl}$. The adjustment of $\mathrm{pH}$ was conducted to run the experiments under the optimum oxidation conditions obtained by López Zavala and Espinoza Estrada (2016) for synthetic solutions ( $\mathrm{pH} 3)$. Then, the solutions were treated electrochemically at DC densities of $5.7 \mathrm{~mA} / \mathrm{cm}^{2} 6 \mathrm{~V}$ ) and $7.6 \mathrm{~mA} /$ $\mathrm{cm}^{2}(12 \mathrm{~V})$ and reaction times $1,2.5,5,7.5,10,15,20,25,30$, $35,40,50,60,120,240,360$, and $540 \mathrm{~min}$. All tests were conducted by triplicate on batch configuration. For each reaction time, samples were taken and filtered using $0.45 \mu \mathrm{m}$ polytetrafluoroethylene syringe filters. Then, they were analyzed by triplicate using an Agilent 1200 HPLC-DAD equipment (Agilent Technologies).

Separation of analytes was conducted by using a $150 \times 4.6 \mathrm{~mm}$ reverse phase monomeric Zorbax C18 column with $5 \mu \mathrm{m}$ diameter spherical particles (MAC-MOD Analytical, Wilmington, DE). Analysis of the paracetamol and its oxidation products was conducted based on the procedure reported by Alkharfy and Frye (2001). The mobile phase used was methanol and $1 \%$ acetic acid in ultrapure water (40/60/v/v) and the operating conditions of the equipment were flowrate of $1.0 \mathrm{~mL} / \mathrm{min}$, temperature $25^{\circ} \mathrm{C}$, detection at $254 \mathrm{~nm}$, and injection volume of $20 \mu \mathrm{L}$.

\section{Results and Discussion}

\section{Surface water characterization}

Raw surface water had low constituent load. Analysis by triplicate of raw surface water samples gave the following results: pH, 7.98; EC, 0.33 mS/cm; turbidity, 5.0 NTU; COD, $130.88 \mathrm{mg} /$ $\mathrm{L}$; TS, $113 \mathrm{mg} / \mathrm{L}$; and TDS, $97 \mathrm{mg} / \mathrm{L}$. Paracetamol traces in raw surface water were unable to be detected by high-performance liquid chromatography with diode-array detection (HPLC-DAD) at $254 \mathrm{~nm}$. Once prepared, the $10 \mathrm{mg} / \mathrm{L}$ paracetamol solutions with surface water, the $\mathrm{pH}$ changed from 7.98 to 6.8 .

\section{Degradation of paracetamol in surface water}

Paracetamol in surface water was totally degraded by using the electrochemical oxidation cell reported by López Zavala and Espinoza Estrada (2016). Figure 3 shows the decay of the paracetamol at $\mathrm{pH} 3$ and DC densities of $5.7 \mathrm{~mA} / \mathrm{cm}^{2}(6 \mathrm{~V})$ and $7.6 \mathrm{~mA} / \mathrm{cm}^{2}$. As seen in Fig. 3, degradation of the paracetamol was faster at $7.6 \mathrm{~mA} / \mathrm{cm}^{2}$. At $5 \mathrm{~min}$ reaction time, the pharmaceutical had been degraded $82 \%$, while at $5.7 \mathrm{~mA} / \mathrm{cm}^{2}$, the degradation was $\sim 27 \%$. Similarly, at $15 \mathrm{~min}$ reaction time, the decay of the paracetamol was $95 \%$ at $7.6 \mathrm{~mA} / \mathrm{cm}^{2}$ and nearly

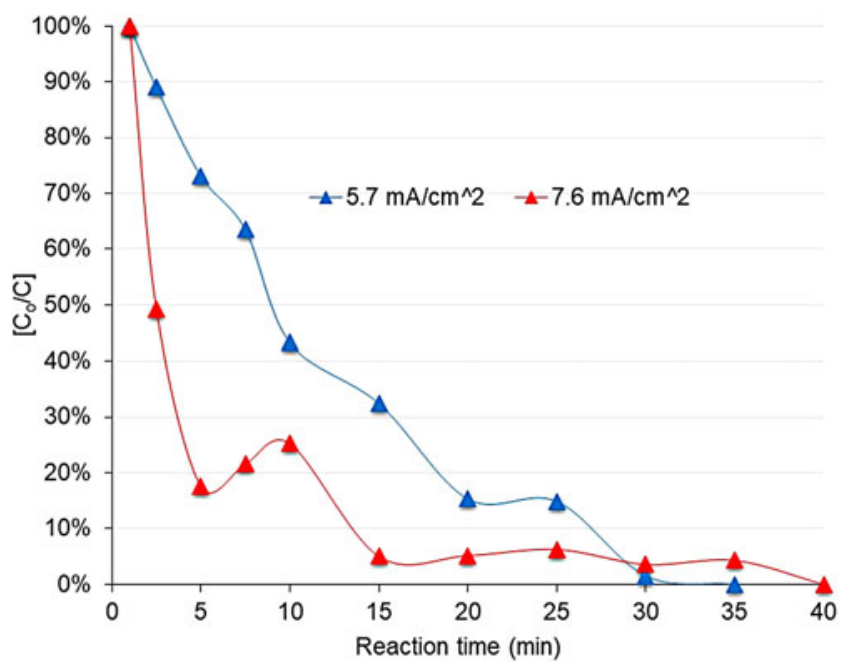

FIG. 3. Decay of paracetamol at $\mathrm{pH} 3$ and DC densities of 5.7 and $7.6 \mathrm{~mA} / \mathrm{cm}^{2}$. The figure shows the average of three replicates. DC, direct current. 
$70 \%$ at $5.7 \mathrm{~mA} / \mathrm{cm}^{2}$. Total degradation was achieved within 35 and $40 \mathrm{~min}$ for both current densities. López Zavala and Espinoza Estrada (2016) reported total degradation of paracetamol in synthetic solutions at similar reaction time for $5.7 \mathrm{~mA} / \mathrm{cm}^{2}$ current density, while at $7.6 \mathrm{~mA} / \mathrm{cm}^{2}$, total degradation occurred at 7.5 min reaction time, much shorter than in surface water.

Higher current density might enhance the deposition of sludge and hydroxides on the electrodes, which can inhibit the electrolysis process and interfere with the passage of current (Garcia-Segura et al. 2017), thus limiting the direct oxidation of the $\mathrm{Cl}^{-}$ion at the anode. Less soluble chlorine formation might delay the oxidation of paracetamol in surface water. As mentioned above, surface water was conditioned with $\mathrm{HCl}$ to reach a $\mathrm{pH} 3$; then, chloride ions are present due to the dissociation of the $\mathrm{HCl}$ into $\mathrm{H}^{+}$and $\mathrm{Cl}^{-}$. Oxidation of paracetamol under these conditions is based on the direct oxidation of the $\mathrm{Cl}^{-}$ion at the anodes to form soluble chlorine $\left(\mathrm{Cl}_{2}\right)$, which is hydrolyzed and transformed into hypochlorous acid (HClO) according to Reactions (1) to (3):

$$
\begin{gathered}
2 \mathrm{Cl}^{-} \rightarrow \mathrm{Cl}_{2}(\mathrm{aq})+2 \mathrm{e}^{-}, \\
\mathrm{Cl}_{2}(\mathrm{aq})+\mathrm{H}_{2} \mathrm{O} \rightleftarrows \mathrm{HClO}+\mathrm{Cl}^{-}+\mathrm{H}^{+},
\end{gathered}
$$

At $\mathrm{pKa}=7.55$, hypochlorous acid is in equilibrium with hypochlorite ion

$$
\mathrm{HClO} \rightleftarrows \mathrm{ClO}^{-}+\mathrm{H}^{+},
$$

Thus, degradation activity of "active" anodes (stainless steel electrodes) used in the electro-oxidation cell was re- markably enhanced by the presence of chloride ions in the surface water solution, as it was reported by López Zavala and Espinoza Estrada (2016) for synthetic paracetamol solutions.

\section{Degradation of paracetamol oxidation products}

Electro-oxidation of the paracetamol with active chlorine generated oxidation products. Therefore, these compounds had to be also degraded because of their potential toxicity. The chromatograms of Figs. 4 and 5 show the paracetamol degradation, the formation of oxidation products, and their degradation at DC densities 5.7 and $7.6 \mathrm{~mA} / \mathrm{cm}^{2}$, respectively. Three oxidation products were detected and denoted as OP 1 (detention time $2.3 \mathrm{~min}$ ), OP 2 (detention time $2.9 \mathrm{~min}$ ), and OP 3 (detention time $3.8 \mathrm{~min}$ ). These three oxidation products were the same detected by López Zavala and Espinoza Estrada (2016) in synthetic solutions. Their identification was not the scope of this work; nevertheless, they could correspond to those referred by the literature, such as 1,4- benzoquinone, p-aminophenol, p-nitrophenol, hydroquinone, and NAPQI (N-acetyl-benzoquinone imine) (Bedner and Maccrehan, 2006; Moctezuma et al., 2012; Postigo and Richardson, 2014). As seen, the three oxidation products, observed by HPLC-DAD at $254 \mathrm{~nm}$, were degraded successfully at both current densities.

At $5.7 \mathrm{~mA} / \mathrm{cm}^{2}$, the oxidation products appeared immediately as the paracetamol is degraded and increased rapidly to reach the maximum detection when the pharmaceutical is already degraded $(35-40 \mathrm{~min})$; then, their detection decreased rapidly to $60 \mathrm{~min}$ detention time and, finally, they
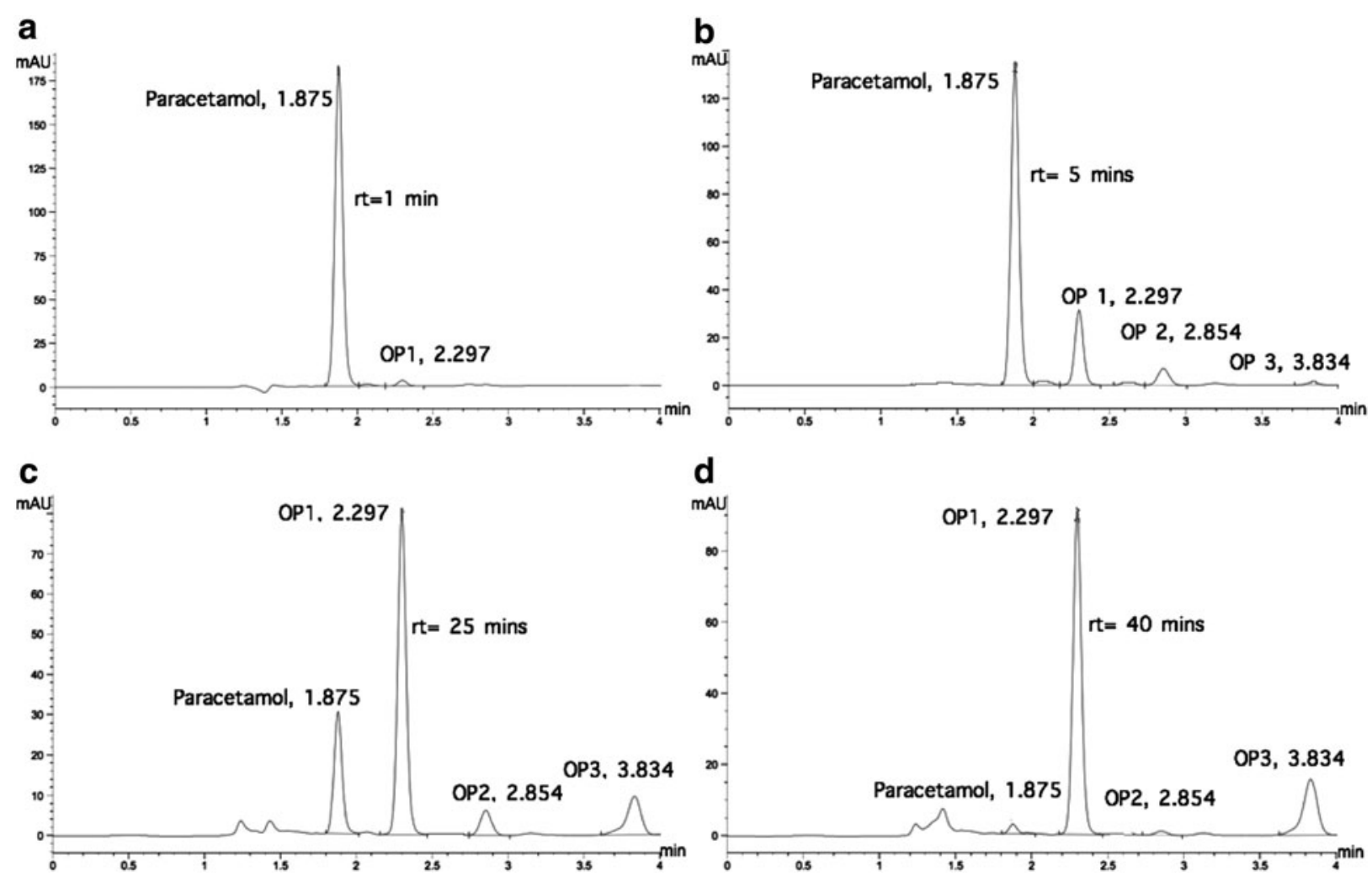

FIG. 4. Chromatograms of paracetamol degradation and its oxidation products at different reaction times, with pH 3 and current density of $5.7 \mathrm{~mA} / \mathrm{cm}^{2}$. (a) $\mathrm{rt}=1 \mathrm{~min} ;$ (b) $\mathrm{rt}=5 \mathrm{~min} ;(\mathbf{c}) \mathrm{rt}=25 \mathrm{~min} ;$ (d) $\mathrm{rt}=40 \mathrm{~min}$. OP refers to oxidation products. 

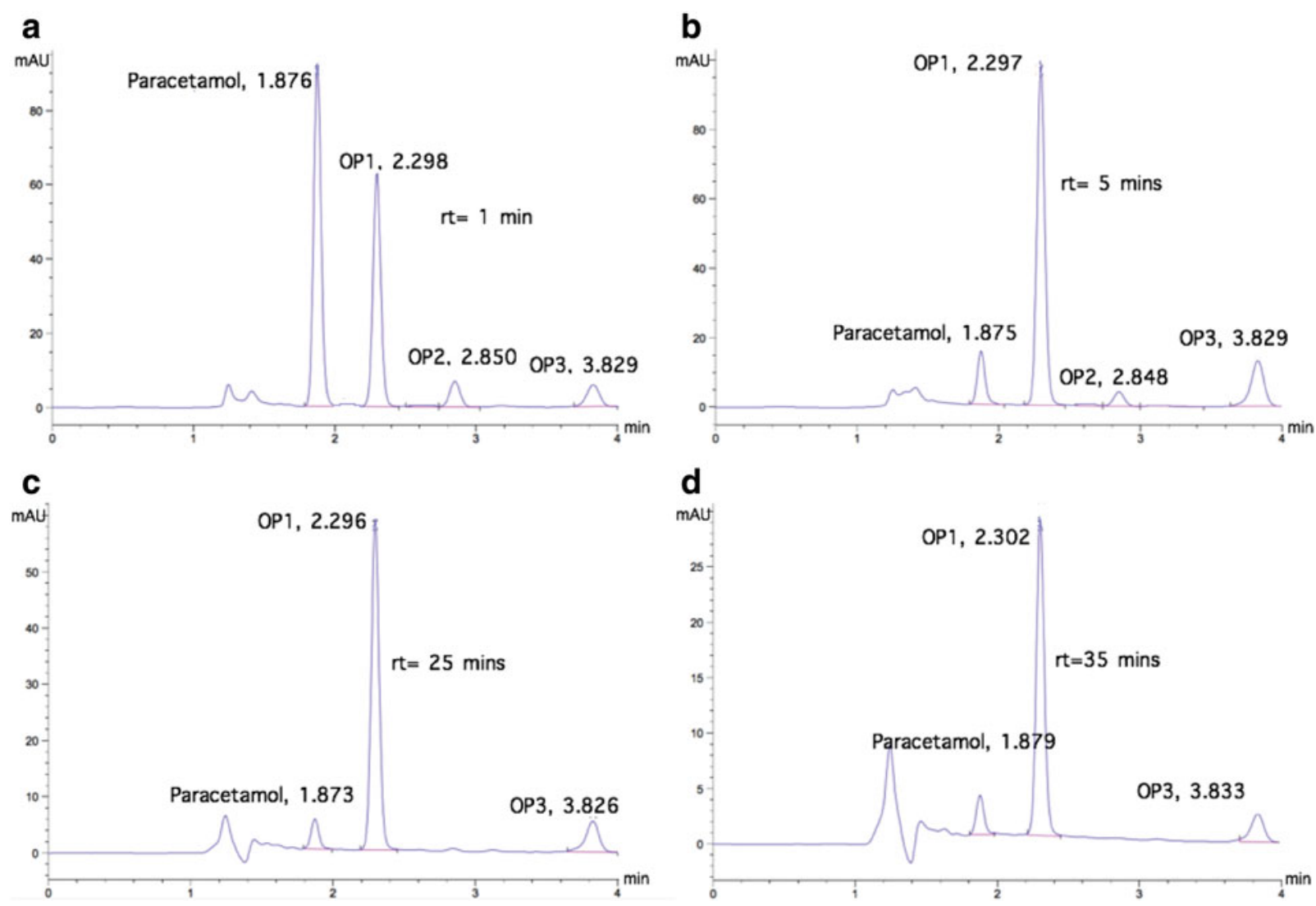

FIG. 5. Chromatograms of paracetamol degradation and its oxidation products at different reaction times, with $\mathrm{pH} 3$ and current density of $7.5 \mathrm{~mA} / \mathrm{cm}^{2}$. (a) $\mathrm{rt}=1 \mathrm{~min}$; (b) $\mathrm{rt}=5 \mathrm{~min}$; (c) $\mathrm{rt}=25 \mathrm{~min}$; (d) $\mathrm{rt}=35 \mathrm{~min}$. OP refers to oxidation products.

were not detected at $240 \mathrm{~min}$ reaction time (Fig. 6). At $7.6 \mathrm{~mA} / \mathrm{cm}^{2}$, the oxidation products were also formed immediately as the paracetamol degradation started, but the detection peak was achieved faster, at only 5 min detention time; then, the detection decreased gradually to $60 \mathrm{~min}$ de-

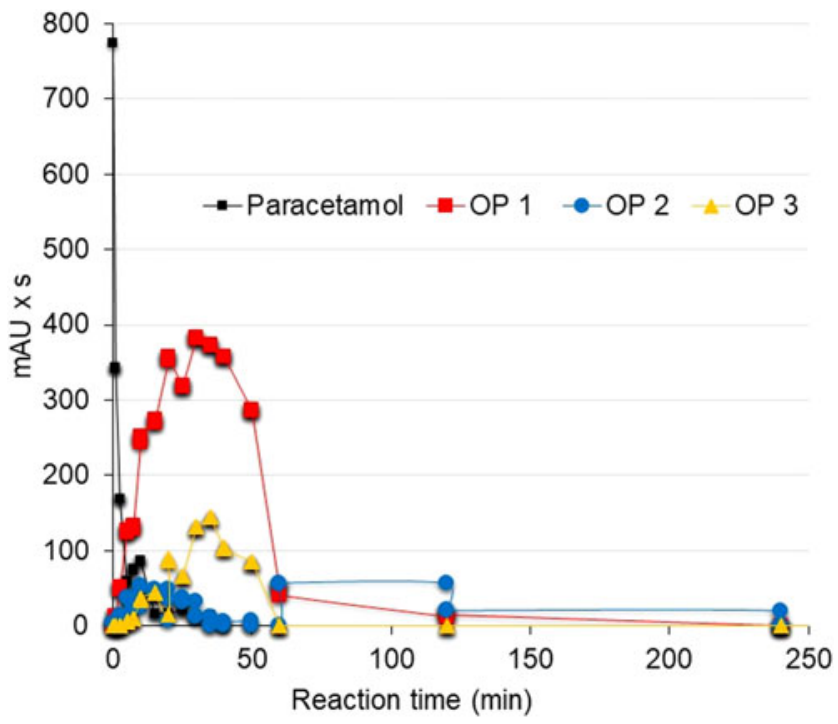

FIG. 6. Degradation of oxidation products at $\mathrm{pH} 3$ and current density $5.7 \mathrm{~mA} / \mathrm{cm}^{2}$. The figure shows the average of three replicates. tention time and, finally, their detection was not observed at $120 \mathrm{~min}$ (Fig. 7). These reaction times are shorter than those values reported by López Zavala and Espinoza Estrada (2016) for synthetic solutions, $360 \mathrm{~min}$ at $5.7 \mathrm{~mA} / \mathrm{cm}^{2}$ and $240 \mathrm{~min}$ at $7.6 \mathrm{~mA} / \mathrm{cm}^{2}$.

In addition, in surface water, the decay of oxidation products occurred rapidly once the generation peaks were reached, while in the synthetic solution, their decay is steady downhill until they are no longer detected. The higher $\mathrm{HCl}$ concentration needed to acidify surface water, in comparison with the synthetic paracetamol solution, could result in a higher chloride concentration and consequently in a greater oxidation of the $\mathrm{Cl}^{-}$ion at the anode. Thus, greater soluble chlorine formation could enhance the degradation of paracetamol oxidation products. These results are promising for practical applications because short reaction times and low current densities are required to achieve full degradation of paracetamol and its oxidation products.

Furthermore, current densities of $7.6 \mathrm{~mA} / \mathrm{cm}^{2}(12 \mathrm{~V})$ can be potentially supplied with photovoltaic cells. Thus, the approach presented in this study could become a potential sustainable technological alternative for degrading emergent contaminants. Certainly, more research must be conducted to (1) elucidate the chemical interactions/processes that are occurring between the paracetamol and its oxidation products with the surface water constituents, and (2) evaluate the degradation of other pharmaceuticals, hormones, personal care products (PCPs), and pesticides under low, neutral, and alkaline $\mathrm{pH}$. 


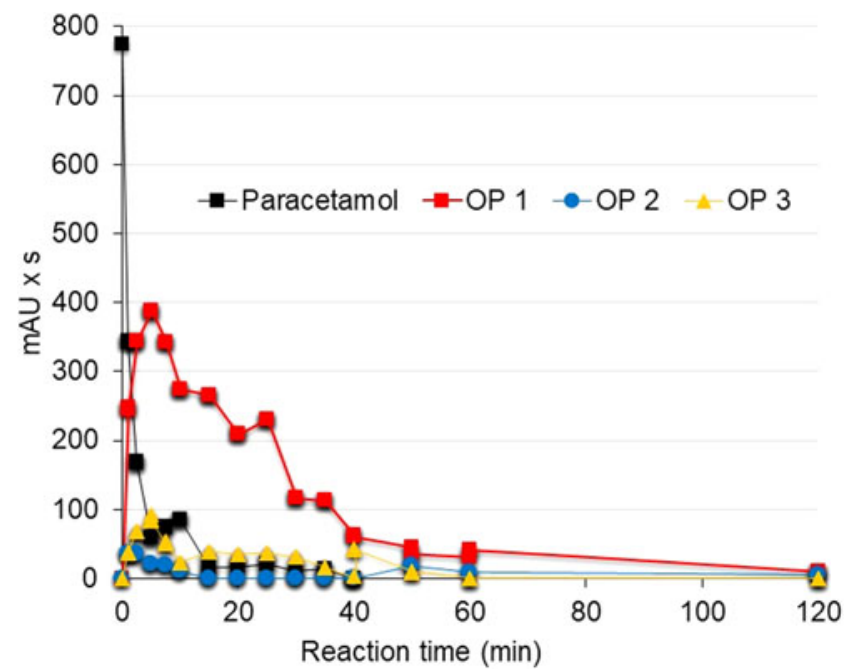

FIG. 7. Degradation of oxidation products at $\mathrm{pH} 3$ and current density $7.6 \mathrm{~mA} / \mathrm{cm}^{2}$. The figure shows the average of three replicates.

\section{Conclusion}

Paracetamol solutions prepared with surface water were oxidized electrochemically at $\mathrm{pH} 3$ and current densities of $5.7 \mathrm{~mA} / \mathrm{cm}^{2}(6 \mathrm{~V})$ and $7.6 \mathrm{~mA} / \mathrm{cm}^{2}(12 \mathrm{~V})$ using the stainless steel electrode cell reported by López Zavala and Espinoza Estrada (2016). The paracetamol was totally degraded in very short reaction times (35 to $40 \mathrm{~min}$, respectively). In comparison with the results reported by López Zavala and Espinoza Estrada (2016) for electrochemical oxidation of paracetamol in synthetic solutions, the degradation of the pharmaceutical was faster in surface water than in the synthetic solution at $5.7 \mathrm{~mA} / \mathrm{cm}^{2}(120 \mathrm{~min}$ reaction time in synthetic solution).

The higher $\mathrm{HCl}$ concentration needed to acidify surface water, in comparison with synthetic paracetamol solution, could result in a higher chloride concentration and consequently in a greater oxidation of the $\mathrm{Cl}^{-}$ion at the anode. Thus, greater soluble chlorine formation could enhance the degradation rate of paracetamol. Nevertheless, at $7.6 \mathrm{~mA} / \mathrm{cm}^{2}$, the total degradation of paracetamol in surface water was delayed up to $40 \mathrm{~min}$, versus the $7.5 \mathrm{~min}$ in the synthetic solution. Deposition of sludge and hydroxides on the electrodes can inhibit the electrolysis process and interfere with the passage of current, thus limiting the direct oxidation of $\mathrm{Cl}^{-}$ that causes less formation of active chlorine species and consequently, longer reaction time.

Three oxidation products, observed by HPLC-DAD at $254 \mathrm{~nm}$, in the paracetamol degradation were totally oxidized. In comparison with the synthetic solution, degradation of such oxidation products in surface water $(240$ and $120 \mathrm{~min}$, respectively) was faster than in the synthetic solution (360 and $240 \mathrm{~min}$, respectively) for 5.7 and $7.6 \mathrm{~mA} / \mathrm{cm}^{2}$ current densities. The higher $\mathrm{HCl}$ concentration needed to acidify the surface water, in comparison with the synthetic paracetamol solution, could result in a higher chloride concentration and consequently in greater oxidation of the $\mathrm{Cl}^{-}$ion at the anode. Thus, greater soluble chlorine formation could enhance the degradation of the paracetamol oxidation products. Higher current density resulted in faster degradation of the oxidation products.
Undoubtedly, more research is needed to elucidate the chemical interactions/processes that are enhancing the degradation rates of the oxidation products in surface water. However, the results obtained in this work are promising for practical applications because short reaction times and low current densities are needed. These current densities can be potentially supplied by photovoltaic cells, thus making the electrochemical oxidation process a potential sustainable technological alternative for degrading emergent contaminants.

\section{Acknowledgment}

This work was supported by the Tecnológico de Monterrey.

\section{Author Disclosure Statement}

No competing financial interests exist.

\section{References}

Abidin, Z.Z., Downes, L., and Markx, G.H. (2007). Novel electrode structures for large-scale dielectrophoretic separations based on textile technology. J. Biotechnol. 130, 183.

Alkharfy, K.M., and Frye, R.F. (2001). High-performance liquid chromatographic assay for acetaminophen glucuronide in human liver microsomes. J. Chromatogr. B. 753, 303.

Al-Rifai, J.H., Gabelish, C.L., and Schäfer, A.I. (2007). Occurrence of pharmaceutically active and non- steroidal estrogenic compounds in three different wastewater recycling schemes in Australia. Chemosphere. 69, 803.

Anglada, A., Urtiaga, A.M., and Ortiz, I. (2009). Contributions of electrochemical oxidation to waste-water treatment: Fundamentals and review of applications. J. Chem. Technol. Biotechnol. 84, 1747.

APHA, AWWA, WEF (2005). Standard Methods for the Examination of Water and Wastewater, 20th ed. APHA, AWWA, WEF.

Baloul, Y., Aubry, O., Rabat, H., Colas, C., Maunit, B., Hong, D. (2016). Degradation of Paracetamol in Aqueous Solution by Non Thermal Plasma. 15th High Pressure Low Temperature Plasma Chemistry Symposium (HAKONE 15), Brno, Czech Republic.

Basavaraju, M., Mahamood, S., Vittal, H., and Shrihari, S. (2011). A novel catalytic route to degrade paracetamol by Fenton process. Int. J. Res. Chem. Environ. 1, 157.

Bedner, M., and Maccrehan, W.A. (2006). Transformation of acetaminophen by chlorination produces the toxicants $1,4-$ benzoquinone and N-acetyl-p-benzoquinone imine. Environ. Sci. Technol. 40, 5516.

Bolong, N., Ismail, A.F., Salim, M.R., and Matsuura, T. (2009). A review of the effects of emerging contaminants in wastewater and options for their removal. Desalination. 239, 229. Brillas, E., Sirés, I., Arias, C., Cabot, P.L., Centellas, F., Rodríguez, R.M., and Garrido, J.A. (2005). Mineralization of paracetamol in aqueous medium by anodic oxidation with a boron-doped diamond electrode. Chemosphere. 58, 399.

Brind, A.M. (2007). Drugs that damage the liver. Medicine. 35, 26. Durán, A., Monteagudo, J.M., Carnicer, A., and Ruiz-Murillo, M. (2011). Photo-Fenton mineralization of synthetic municipal wastewater effluent containing acetaminophen in a pilot plant. Desalination. 270, 124.

Edrees, W.H.A., Abdullah, Q.Y.M., Al-Kaf, A.G., and Naji, K.M. (2017). A review on comparative study between the physicochemical and biological processes for paracetamol degradation. Uni. J. Pharm. Res. 2, 12. 
Ganiyat, A.M. (2008). The toxicological evaluation of sewage effluents and pharmaceuticals with the use of zebrafish as a model organism. Master of Science Programme in Veterinary Medicine for International Students. Faculty of Veterinary Medicine and Animal Science. Swedish University of Agricultural Sciences, Uppsala, Sweden, 7, 1403.

Garcia-Segura, S., Eiband, M.M.S.G., Vieira de Melo, J., and Martínez-Huitle, C.A. (2017). Electrocoagulation and advanced electrocoagulation processes: A general review about the fundamentals, emerging applications and its association with other technologies. J. Electroanal. Chem. 801, 267.

Hiremath, D.C., Hiremath, C.V., and Nandibewoor, S.T. (2006). Oxidation of paracetamol drug by a new oxidant diperiodatoargentate (III) in aqueous alkaline medium. E. J. Chem. $3,13$.

Jaeschke, H., and Bajt, M.L. (2006). Intracellular signaling mechanisms of acetaminophen-induced liver cell death. Toxicol. Sci. 89, 31.

Kanakaraju, D., Glass, B.D., and Oelgemöller, M. (2014). Titanium dioxide photocatalysis for pharmaceutical wastewater treatment. Environ. Chem. Lett. 12, 27.

Kasprzyk-Hordern, B., Dinsdale, R.M., and Guwy, A.J. (2009). The removal of pharmaceuticals, personal care products, endocrine disruptors and illicit drugs during wastewater treatment and its impact on the quality of receiving waters. Water Res. 43, 363.

López Zavala, M.A., and Espinoza Estrada, E. (2016). Degradation of acetaminophen and its transformation products in aqueous solutions by using an electrochemical oxidation cell with stainless steel electrodes. Water. 8, 383.

Lourenção, B.C., Medeiros, R.A., Filho, R.C.R., Mazo, L.H., and Filho, O.F. (2009). Simultaneous voltammetric determinate on of paracetamol and caffeine in pharmaceutical formulations using a boron-doped diamond electrode. Talanta. 78, 748.

Moctezuma, E., Leyva, E., Aguilar, C.A., Luna, R.A., and Montalvo, C. (2012). Photocatalytic degradation of paracetamol: Intermediates and total reaction mechanism. $\mathrm{J}$. $\mathrm{Ha}$ zard. Mater. 243, 130.

Nematollahi, D., Shayani-Jam, H., Alimoradi, M., and Niroomand, S. (2009). Electrochemical oxidation of acetaminophen in aqueous solutions: Kinetic evaluation of hydrolysis, hydroxylation and dimerization processes. Electrochimica. Acta. 54, 7407.
Postigo, C., and Richardson, S.D. (2014). Transformation of pharmaceuticals during oxidation/disinfection processes in drinking water treatment. J. Hazard. Mater. 279, 461.

Quesada-Peñate, I., Julcour Lebigue, C., Jáuregui Haza, U.J., Wilhelm, A.M., and Delmas, H. (2009). Sonolysis of levodopa and paracetamol in aqueous solutions. Ultrason. Sonochem. 16, 610.

Rossner, A., Snyder, S.A., and Knappe, D.R. (2009). Removal of emerging contaminants of con cern by alternative adsorbents. Water Res. 43, 33787.

Sánchez-Obrero, M., Mayén, G., Mellado, J.M.R., and Rodríguez-Amaro, R. (2011). Electrocatalytic oxidation of acetaminophen on a PVC/TTF-TCNQ composite electrode modified by gold nanoparticles: Application as an amperometric sensor. Int. J. Electrochem. Sci. 6, 2001.

Solé, M., Shaw, J.P., Frickers, P.E., Readman, J.W., and Hutchinson, T.H. (2010). Effects on feeding rate and biomarker responses of marine mussels experimentally exposed to propranolol and acetaminophen. Anal. Bioanal. Chem. $396,649$.

Trovó, A.G., Pupo Nogueira, R.F., Agüera, A., Fernandez-Alba, A.R., and Malato, S. (2012). Paracetamol degradation intermediates and toxicity during photo-Fenton treatment using different iron species. Water Res. 46, 5374.

Westerhoff, P., Yoon, Y., Snyder, S., and Wert, E. (2005). Fate of endocrine-disruptor, pharmaceutical, and personal care product chemicals during simulated drinking water treatment. Environ. Sci. Technol. 39, 66649.

Wu, S., Zhang, L., and Chen, J. (2012). Paracetamol in the environment and its degradation by microorganisms. Appl. Microbiol. Biotechnol. 96, 875.

Xu, J.J., Hendriks, B.S., Zhao, J., and Graaf, D. (2008). Multiple effects of acetaminophen and p38 inhibitors: Towards pathway toxicology. FEBS. Lett. 582, 1276.

Yang, L., Yu, L.E., and Ray, M.B. (2008). Degradation of paracetamol in aqueous solutions by $\mathrm{TiO}_{2}$ photocatalysis. Water Res. 42, 3480.

Zhang, X., Wu, F., Wu, X.W., Chen, P.Y., and Deng, N.S. (2008). Photodegradation of acetaminophen in $\mathrm{TiO} 2$ suspended solution. J. Hazard. Mater. 157, 300.

Zhao, X., Hou, Y., Liu, H., Qiang, Z., and Qu, J. (2009). Electro-oxidation of diclofenac at boron doped diamond: Kinetics and mechanism. Electrochimica. Acta. 54, 4172. 